The final chapter, which does try to map out some positive implications of Wittgenstein's work, although interesting in itself, sits rather oddly with the rest of the book, given its (the chapter's) concern with the collective and the political rather than the individual self and the ethical. Nevertheless, in spite of the above criticisms, reading Tanesini's book, in particular Chapters Three and Four, has made me want to read Wittgenstein again. Moreover, it has convinced me that his early as well as his later work is and should be of interest to feminist philosophers. The book provides both fascinating insights into Wittgenstein's philosophical project and a reminder of the capacity of feminist readings to illuminate new avenues for philosophical inquiry within very familiar canonic texts.

doi:10.1057/palgrave.fr. 9400329

Kimberly Hutchings

\title{
Recovering subversion: feminist politics beyond the law
}

Nivedita Menon; Permanent Black, Urbana and Chicago, 2004, ISBN 0-252-02969-0, £48.00 (hbk), ISBN 0-252-0721l-1, £19.95 (pbk)

In Recovering Subversion, Nivedita Menon examines the relationship between radical feminist politics and the use of law for social change. The text focuses on issues central to the contemporary Indian women's movement and provides detailed analysis of politics, practices and law reform since the 1980s. Menon's comprehensive exploration describes significant limitations for the women's movement engagement with law in order to advance feminist politics. Menon examines the efficacy of utilizing the language of rights for social change and ultimately argues against law as having potential to enact comprehensive transformation for the ethical and emancipatory impulses of feminist politics.

The central focus of the text outlines the problematic of 'the 'paradox of constitutionality" (p. 2), which Menon analyses through a feminist perspective. Menon suggests that for feminist politics, differing moral visions must be asserted; women's diverse experiences 'as 'real' ... acquires meaning precisely through an interplay of contexts, and may be rendered sterile within the rigid codification required within legal discourse' (p. 107). She argues that this problem becomes apparent in pursuing recognition of these experiences, as legal discourse works by 'fixing meaning, by creating uniform categories out of a multiplicity of possibilities, by suturing open-endedness' (p. 107). Therefore, Menon's analysis contends that legal discourse is not only insufficient for 
feminist politics, but can work to consolidate dominant norms and therefore undermine the need for differing moral visions to be asserted and qualified as legitimate.

In illustrating the inherent problematic of using law as a progressive force for feminist politics, Menon's first chapter gives a comprehensive historical and theoretical account of rights discourses. Menon engages with the work of prominent scholars such as Wendy Brown, Jacques Derrida and Nancy Fraser and provides a broad overview of debates on rights. Utilizing the debates put forward by these commentators, she provides a critique of rights for their particular historical and political emergence, their privileging of state interests and in the context of India, their reflection of interests of higher castes. Therefore, Menon questions the 'assumption underlying understandings of rights, that these are universal and based on a generally accepted moral order' (p. 26). She illustrates that even international human rights have a specificity of emergence and produce a particular, central moral vision that does not reflect the more expansive feminist view of multiple meanings, norms and experiences.

The text is then divided into three sections, focusing on important and contemporary issues for the Indian women's movement; abortion and femicide of foetuses; sexual violence and the campaign for reservations for women in Parliament. All three chapters provide detailed tracing of legal discourse on the issues and engage with the complexities of feminist politics in using law to enact social and political change. The chapter 'Abortion: When Pro-Choice is Anti Women', is particularly interesting, illustrating the problematic for feminist engagement with the complexities of politics surrounding reproduction in India. Abortion has been legal in India since 1971, but 'originated from the population control imperatives of the Indian state, not from feminist politics' (p. 66). For feminist analyses of abortion, the legal discourse has become complicated by cultural specificity and the need to reject selective abortion of female foetuses. The dilemma has therefore arisen whereby 'Indian feminists have found themselves in the paradoxical position of demanding curbs on access to abortion' (p. 66). The issue does not lend itself to a definitive feminist or legal understanding, with the claim to rights being asserted for both the right of the mother to choose and the right to life of the foetus. After detailed description of the arguments, Menon concludes that 'feminist understandings need to confront the fact that the pro-abortion position is not necessarily a feminist decision to take' (p. 98). Moreover, the rigid categories of law cannot aid such a complex dilemma.

For Menon, furthering 'the ethical and emancipatory impulse of feminism itself' (p. 122), requires new forms of practice and engagement with non-legal forums. She suggests that 'we (feminists as well as other social movements) may have reached the limits of the emancipatory potential of the language of rights' (p. 207). However, it appears premature to disregard the potential of law for 
furthering feminist politics or being a transformative instrument. Menon's exploration of law is largely focused on rights, not other realms such as criminal law and therefore reduces law to a singular domain. This reduction of law is problematic for her argument. To argue against law only in terms of rights fails to consider the multiple sites of law and legal processes. In regards to her critique of universal moral visions provided by law, the failure to move effectively beyond the national to the international, through examination of international criminal law or international notions of human rights, other than David Kennedy's critique of rights, leads to an incomplete picture of arguments that feminists have found useful concerning universal notions of the person. So, for example, feminist work focusing on international law is not engaged within any detail. As international criminal law has demonstrated in its significant revisions of gendered harms, a full exploration of the jurisdiction and how it characterizes gendered violations through criminal wrongs of accused, not rights, would further enhance and perhaps revise Menon's theoretical claims that feminist engagement with law is largely exhausted.

doi: $10.1057 /$ palgrave.fr. 9400335

Claire Garbett

\section{Mommy Queerest. Contemporary rhetorics of lesbian maternal identity}

Julie M. Thompson; University of Massachusetts Press, Amherst \& Boston, 2002,

ISBN 1-55849-355-7, £27.00 (hbk)

There have been significant studies and anecdotal anthologies which explore the everyday experiences of lesbian parent family life and identities; Julie Thompson aims to add a theoretical engagement with the topic through critical rhetoric. Mommy Queerest argues that the category of lesbian mother is discursively constituted as an antithetical identity. She draws on critical and rhetorical principles to explore social and legal representations of lesbian maternity and examines how 'lesbian mother as oxymoron' is negotiated in various forums.

In Chapter One, Thompson introduces lesbian maternity and ideas of lesbian community through a historical exploration of lesbian identity, tracing its emergence through sexological accounts of sexuality into contemporary public (US) debate over the meanings of lesbian motherhood in journalistic, judicial and academic discourses. The following three chapters elaborate on these three areas. Thompson illustrates how journalistic discourses uphold hegemonic 